University of Massachusetts Amherst

ScholarWorks@UMass Amherst

2018

\title{
A Model of the Marxist Rent Theory
}

Debarshi Das

Humanities and Social Sciences Department, Indian Institute of Technology Guwahati

Follow this and additional works at: https://scholarworks.umass.edu/econ_workingpaper

Part of the Economics Commons

\section{Recommended Citation}

Das, Debarshi, "A Model of the Marxist Rent Theory" (2018). UMass Amherst Economics Working Papers. 248.

https://doi.org/10.7275/12237530

This Article is brought to you for free and open access by the Economics at ScholarWorks@UMass Amherst. It has been accepted for inclusion in Economics Department Working Paper Series by an authorized administrator of ScholarWorks@UMass Amherst. For more information, please contact scholarworks@library.umass.edu. 


\title{
A Model of the Marxist Rent Theory
}

\author{
Debarshi Das* \\ Humanities and Social Sciences Department, Indian Institute of Technology Guwahati
}

\begin{abstract}
This paper presents an interpretation of Marx's rent theory. The three forms of rent, differential rent of type one and two, and absolute rent, have been elaborated and represented through algebra. Marx situated his theory in an agrarian economy characterised by the capitalist mode of production. Such conditions are not present in the agrarian economy of India, yet one can still borrow Marx's analytical tools, the paper argues, to understand the contemporary agrarian India. Some observations on Indian agrarian economy have been offered in the end.
\end{abstract}

Keywords: Marx, absolute rent, organic composition of capital, landed property

\section{Introduction}

In Marxist framework, the theory of rent is central to the understanding of production of surplus value in agriculture and its distribution. The third volume of Capital devoted a substantial portion to a discussion of rents of various kinds. It is well known that Capital III was published long after Marx's death. Engels edited and put it together, apart from supplementing it with copious notes. The fact that the third volume was published posthumously could be a reason why the third volume of Capital did not have the touch of finality that the first volume had. But this is not a reason enough to explain why rent theory has seen "fewer comments and developments, by followers and critics alike, than other major parts of his 'system"” (Mandel 1990).

Considering it from the perspective of a developing economy like India the paucity of scholarly engagement appears puzzling. Typically, developing economies have a large agricultural sector providing livelihood to the biggest segment of the population. These countries do not lack the presence of political movements animated by the Marxist vision of social liberation. Yet one does not find many attempts to understand the agrarian scene deploying Marxist rent theory ${ }^{1}$.

\footnotetext{
* debarshidas@iitg.ac.in. I thank Deepankar Basu for valuable comments on an earlier. I also thank participants of a panel discussion at HSS Department, IIT Guwahati organised on the occasion of bicentennial anniversary of Karl Marx for their comments. The errors of the paper are entirely mine.
} 
There can be two possible reasons for this. The first is the theory itself. It has been observed that rent theory is one of the most difficult parts of Marxist economics (Mandel, 1990). There have been conflicting claims over interpretation as well (Fine, 1979). This signals to an analytical terrain whose contours are disputed. Not surprisingly, not many structures have been built on the uncertain ground.

The second reason for the limited progress is the assumption of the framework. In the first chapter on rent in Capital III, i.e. chapter 37, Marx made it clear that the ensuing discussion was applicable to an agrarian economy where the capitalist mode of production has established itself $^{2}$.This precludes many of today's third world countries, including India. Agriculture of India is characterised by production relations which can scarcely be called capitalist. Many of the farms are petty. They mostly depend on family labour rather than wage labour. Production of surplus, its reinvestment and accumulation of capital has been slow. The classic agrarian capitalism that materialised in England, characterised by the triad of the landowning rent-earner, the tenant capitalist farmer and the wage-earning agricultural worker, is not the defining feature of Indian agriculture.

A purpose of this paper is to address both these points. Through an easily understandable, unified mathematical model we shall interpret the three kinds of rent Marx discussed. Marx was not shy of using mathematics. In explaining quantitative notions, which he frequently encountered, Marx resorted to mathematics. He relied on arithmetical examples (mostly) to illustrate general tendencies. Arithmetical examples invite at least two complications. One, they are specific to the numbers chosen. As the number change the results may vary. With his usual thoroughness, Marx took numerous examples to subsume several sub-cases. But this rendered the demonstration messy. Secondly, as the examples are number-specific it is difficult to put the different components of the theory together in a single overarching framework. The use of algebra, which we deploy here, could prove to be helpful in this regard.

This is not an unprecedented attempt. A recent notable work is by Basu (2018). Indeed, this present paper owes a great deal to Basu (2018)'s endeavour to integrate Marx's rent theory in a 
single analytical framework. Our approach has differences with Basu's approach and interpretation. Capital was taken in infinitesimally small units in Basu's paper. This enabled him to apply tools of differential calculus. In Marx's examples capital appears in discrete blocks. There could be theoretical reasons behind this, for instance, investments which are embedded with technology, could be indivisible below a point. There could be practical considerations too, that it made arithmetic examples easier. In this paper we have taken capital in discrete blocks.

Besides framing Marx's rent theory in a single model, the paper addresses the second point of applicability of rent theory in Indian context. Although capitalist mode of production does not characterise Indian agriculture, we shall argue that deployment of rent theory, with qualifications, can be fruitfully done.

The rest of the paper is organised as follows. In section 2 two forms of differential rent are discussed, whereas section 3 takes up absolute rent. Section 4 presents a mathematical model subsuming these rents in a single structure. In section 5 we offer brief comments on the relevance of rent theory to contemporary Indian agriculture. The paper concludes with closing remarks in section 6 .

\section{Differential rents}

Marx was influenced by writers of political economy who preceded him. Two important figures who left impression were Adam Smith and David Ricardo. To Smith rent was a "monopoly price". The Wealth of Nations proposes,

[T] he rent of the land...is naturally a monopoly price. It is not at all proportioned to what the landlord may have laid out upon the improvement of the land, or to what he can afford to take; but to what the farmer can afford to give" (Smith [1776] 1970, p. 249).

That rent arose at a particular historical juncture when land became private property was not lost to Smith: "[a]s soon as the land of any country has all become private property, the landlords, like all other men, love to reap where they never sowed, and demand a rent even for its natural produce" (ibid. p. 152). To Marx's method of historical materialism this made sense, he approvingly quoted this passage in The Theories of Surplus Value (1963). In the same work Marx took Ricardo's definition of rent to task for its ahistoricity. On Ricardo's famous assertion 
that " $[\mathrm{r}] \mathrm{ent}$ is that portion of the produce of the earth, which is paid to the landlord for the use of the original and indestructible powers of the soil" Marx remarked that "[I]t has no "original" powers either, since the land is in no way "original", but rather the product of an historical and natural process".

Marx criticised Ricardian theory. At the same time, he was influenced by it. The idea of differential rent formulated by Ricardo was reflected in Marx's "first from of differential rent" and "second form of differential rent". Ricardo had emphasised on the objective basis of rent. The basis could be higher soil fertility, for instance. Marx also sought to formulate his theory of rent on a material foundation. But he did not borrow the Ricardian concepts blindly. Marx emphasised on the monopoly power exercised by landlords, without which rents cannot exist. Marxian divided differential rents into two categories: the first form of differential rent (DR $I)$, and the second form of differential rent $(D R I I)$. We discuss these two types of rent next.

\subsection{Differential Rent I}

Differential rent of type I arises due to difference in soil quality (or the location of the site of cultivation). Suppose there are two land plots of equal size: land 1 and land 2. Land 1 is more fertile than land 2. With the same amount of capital, land 1 would produce more crop than 2. Putting it in another way, compared to a situation where only 1 is cultivated, in order to make the cultivation of 2 feasible, the price of the crop has to rise. If the price remains low, it may not be worthwhile for a farmer to cultivate 2 . With low price, revenue from the harvest of land 2 would be lower than the cost. If price is high and land 2 is indeed cultivated, then it means that in land 1 a surplus of revenue over cost and normal profit would be generated. This surplus is termed as "surplus profit". If the old lease continues, and the price rises in the meantime, the capitalist farmer of 1, who has rented the land from the landlord, would pocket the surplus. It is an addition over his normal profit. When the lease of land 1 is renewed, the landlord would include this surplus profit as rent to be paid him in the new lease agreement. The surplus profit is thus transformed into "capitalist ground-rent". The supernormal high profit that the capitalist farmer had earned earlier would cease to exist. Hence no difference in profit rates across sectors, or across plots, would persist. 
The notion of differential rent, apparently, depends on difference of soil fertility. Hence the Ricardian insistence that rent is paid for the indestructible and original quality of soil. But this overlooks the implicit condition that landlords have monopoly right over lands. On the relation of landed property and surplus profit (which transforms into rent), Marx (1981[1894], p. 786) observed,

This surplus profit exists even if there is no landed property...landed property does not create the portion of value that is transformed into surplus profit... It [landed property] is not the cause of this surplus profit's creation, but simply of its transformation into the form of ground-rent.

Difference in soil fertility creates surplus profit in superior plots. But by itself it does not create $D R I$. This was Ricardo's folly. To explain rent one needs the existence of landed property in addition to "power of the soil".

\subsection{Differential Rent II}

The condition depicted above is a hypothetical one where land plots received the same volume of capital investment. In general they may have different volumes of capital investments. Marx (usually) handled this possibility by considering that multiple units of the same magnitude of capital ( $£ 2.5$ ) have been invested on plots of land. Some plots end up with more capital than others because they receive more units of capital.

Multiple units of capital invested on lands may generate $D R I I$. Let us rephrase Marx's example of DR II in chapter 40, Capital III to illustrate this. Let us assume that three units of capital of equal magnitude are applied one after another on the same land. These three units capital have different yields, they produce $y_{1}, y_{2}, y_{3}$ respectively, where $y_{1}>y_{2}>y_{3}{ }^{3}$. The last dose of capital is applied only if price of crops is high enough to cover the cost as well as the normal profit on capital. If the price is at such a high level, the first and second doses of capital would produce surplus profit. When the lease is renewed this surplus profit accrues to the landlord as $D R I I$.

$D R I I$ is similar in nature to $D R I$. In both cases different units of capital (of same magnitude) produce different levels of output. In DR I, output from two different lands are compared. Since other things including capital remain the same, except fertility, rent is attributed to fertility 
difference. In $D R I I$, as we have illustrated above capitals produce different outputs. The site of capital investment may be the same, as in the above example, or they may be different, as discussed in chapter 44 of Capital III. DR II is generlisation of DR I, for eventually investment of capital produces output - whether the land is the same or not is not of primary concern. As Marx (1981[1894], p. 816) mentioned, "differential rent II is simply a different expression of differential rent I, and the same thing as far as its nature is concerned."

A few definitional issues are in order before we proceed further. Marx (1981[1894], p. 873) used the phrase "price of production" to denote "the sum of capital advanced plus 20 percent profit". In other words, price of production is the capital outlay plus the normal profit on that capital. This is confusing, because in today's nomenclature "price" is used to mean price per unit of output, not "the sum of capital advanced". Hence we use "unit price of production" to denote price of production per unit of output. It is equal to cost of production per unit of output plus the normal profit per unit of output. We use the phrase "total price of production" to denote what Marx called the price of production. It's the aggregate price of production of all units of output obtained from a particular investment.

When multiple capitals are invested on a plot of land there is a possible confusion regarding which unit price of production is the ruling price. Different doses of capital are of differing productivity and have different prices of production. Is it the average unit price of production of all capitals, or the unit price of production of the marginal capital, which governs the price of production? An arithmetic example is given in table 1 to elaborate.

Two successive doses of capital each worth 50 monetary units are applied on the same land. The normal rate of profit is assumed to be $20 \%$, hence the total price of production of each dose of capital is $60(=50 \times 1.2)$. The outputs from these two doses are 4 and 2 units respectively. The unit price of production of the first and the second doses of capital therefore are $15\left(=\frac{60}{4}\right)$ and $30\left(=\frac{60}{2}\right)$ respectively. If the prevailing market price is 30 , i.e. the unit price of production of the marginal capital, then the $1^{\text {st }}$ capital will earn surplus profit of 60 . This is $D R I I$ according to our definition. 


\begin{tabular}{|l|l|l|l|l|l|l|l|l|}
\hline Capital & $\begin{array}{l}\text { Output } \\
\text { (units) }\end{array}$ & $\begin{array}{l}\text { Capital } \\
\text { advanced }\end{array}$ & $\begin{array}{l}\text { Rate of } \\
\text { profit }\end{array}$ & $\begin{array}{l}\text { Unit Price of } \\
\text { production }\end{array}$ & $\begin{array}{l}\text { Total price of } \\
\text { production }\end{array}$ & $\begin{array}{l}\text { Revenue at } \\
\text { price 30 }\end{array}$ & $\begin{array}{l}\text { Surplus } \\
\text { profit }\end{array}$ & \begin{tabular}{l} 
Rent \\
\hline st
\end{tabular} 4 \\
\hline & 50 & $20 \%$ & 15 & 60 & 120 & 60 & 60 \\
\hline 2nd & 2 & 50 & $20 \%$ & 30 & 60 & 60 & 0 & 0 \\
\hline
\end{tabular}

Table 1: DR II when two units of capital are applied on the same land Alternatively one may consider the average unit price of production of both capitals put together. In all 6 units are produced with a total price of production of 120. Thus on average the unit price of production is $20\left(=\frac{120}{6}\right)$. At this price the revenue of the $1^{\text {st }}$ capital is $80(=20 \times 4)$, whereas its total price of production of the $1^{\text {st }}$ capital is 60 . Thus there is a surplus profit of 20 . This is counterbalanced by the deficit of 20 of the $2^{\text {nd }}$ capital (its total price of production is 60 , the revenue is 40 , so there is a deficit of 20). The land does not yield rent. This contradicts the conclusion of the previous paragraph that the rent is $60^{4}$.

How to resolve the contradiction? When multiple units of capital are invested, is it the price of production of the marginal capital or the average price of production that is equal to market price? One may ask the following questions. If the prevailing price is 30 (the first case), will a landlord be able to extract 60 as rent from the land with no surplus profit left? The answer is yes. The tenant would gladly accept the deal of paying 60 as rent. She will invest two doses of capital worth 100 , earn $20 \%$ profit and pay the landlord 60 as table 1 demonstrates. And, if the prevailing price is 20 (the second case), will a landlord get zero rent with no extra surplus profit left? The answer is no. With 20 as the crop price, the farmer would accept the lease and invest only the first capital (for the second capital, the marginal cost, 60 exceed marginal benefit, 40). She will earn a revenue of 80 . His total price of production is 60 ; with 0 rent he would be left with a surplus profit of 20 .

Therefore it is the unit price of production of the marginal capital, not the unit price of the average capital, that governs the price of crop. Taking the price of production of the marginal capital as the benchmark one can estimate DRII. 


\section{Absolute Rent}

So far we have assumed that absolute rent $(A R)$ does not exist. Marx's introduction of $A R$ was a critique of the Ricardian theory.

Does an absolute rent exist? That is, a rent which arises from the fact that capital is invested in agriculture rather than manufacture; a rent which is quite independent of differential rent or excess profits which are yielded by capital invested in better land?

It is clear that Ricardo correctly answers this question in the negative, since he starts from the false assumption that values and average prices of commodities are identical (Marx 1863 , italics in the original)

Like differential rent, exaction of absolute rent requires the existence of landed property. But what is its "natural basis"? Why does a difference between "values and average prices of commodities" arise?

The basis for absolute rent is the low "organic composition of capital" in agriculture. As it is standard in the Marxist value theory, the aggregate capital is divided into two parts: the constant capital $(C)$ and the variable capital $(V)$. $C$ includes outlays made for machines, equipment, raw material and the like, whereas $V$ accounts for the payment for labour power, i.e. the wage bill of workers. For reasons of technological backwardness or otherwise the agricultural capital has lower $C$ per unit of $V$ (Marx [1894] 1981, p. 894). In other words, the rest of the economy is more capital intensive than agriculture. From the point of view of India and other LDCs this does not appear to be an outlandish assumption. The family farms which dominate agriculture of such economies tend to put more labour per unit of other inputs compared to the non-agricultural sector.

The difference in the organic composition implies that the same volume of capital produces different volumes of surplus value. Therefore rates of profit in agricultural and the economy as a whole will differ:

[T] he surplus-value produced in agriculture by a capital of a given size, or, what comes to the same thing, by the surplus labour that it sets in motion and commands (i.e. the total living labour applied), is greater than for an equally large capital of the average social composition. (Marx [1894] 1981, p. 894) 
The rate of profit in agriculture is higher than the social average since surplus value stems from variable capital. Generally, the additional surplus earned by capital in a sector gets distributed across sectors, courtesy competition between capitals. Capital would flow into the sector with higher rate of profit to lap up the extra profit, as a result output would rise. Price, which could have been close to value, would fall. How far shall it fall? The fall will be to the extent that the rate of profit gets equalised across sectors. This uniform rate of profit is the average rate of profit. The prices that are obtained by imputing this uniform, average rate of profit on capitals are prices of production. Since the agricultural sector has an organic composition higher than the social average, the value of its output is higher than its price of production.

However, the spontaneous flow of capital described above, gets stalled due to the presence of landed property. Landed property restricts capital inflow, thereby crop output is kept low and market price remains high. High price guarantees continuation of surplus profit, i.e. AR. The gap between the value of output and price of production remains. This difference gets extracted by landlords in the form of $A R^{5}$. This ensures that value is realized and that value and price are equal even in the least productive investment.

Confusion arises when it is recalled that agricultural sector does not take part in the sharing of the aggregate surplus value of the economy. For agricultural sector as a whole total value produced and must be equal to total revenue. In other words, price and value per unit of output are equal for capital of average productivity. For the least productive capital where value per unit of output is higher than average, value exceeds price. This contradicts the last sentence of the last paragraph. To our mind, the principle of preservation of surplus value in agricultural sector is salient. If this principle determines price, then the price will be lower than what it would be if principle is that the least productive capital realises value. At this low price it is no longer guaranteed that least productive capital earns normal profit rate. We shall show in section 4.3 that a condition in terms of high difference between the organic compositions is required. This condition is similar to the Assumption 3 in Basu (2018).

Let us summarise. Cultivation under capitalist mode of production requires that price of crops cover the cost and profit per unit. We have termed this price as the unit price of production. 
Existence of landed property warrants that landlords be paid rent. $D R I$ arises from the fact that different lands have different productivity levels and all lands yield normal profit (assuming lands have been invested with same volume of capital). As more capital is invested, productivity of successive capitals drops. Price has to rise in order to enable the additional investments. When price rises to such a level, a non-marginal piece of land gets rent from two sources. First, it is more productive than the marginal land and therefore yields $D R I$. Second, investments made on the land could be more productive than the marginal capital. This is the source of DR II. Finally, with the assumption of lower organic composition of capital in agriculture a third force influences the price. Now it is not enough that the marginal capital investment earns the social rate of profit. Additionally, it is necessary that the price be such that surplus value produced in agriculture is retained. This is the source of $A R$.

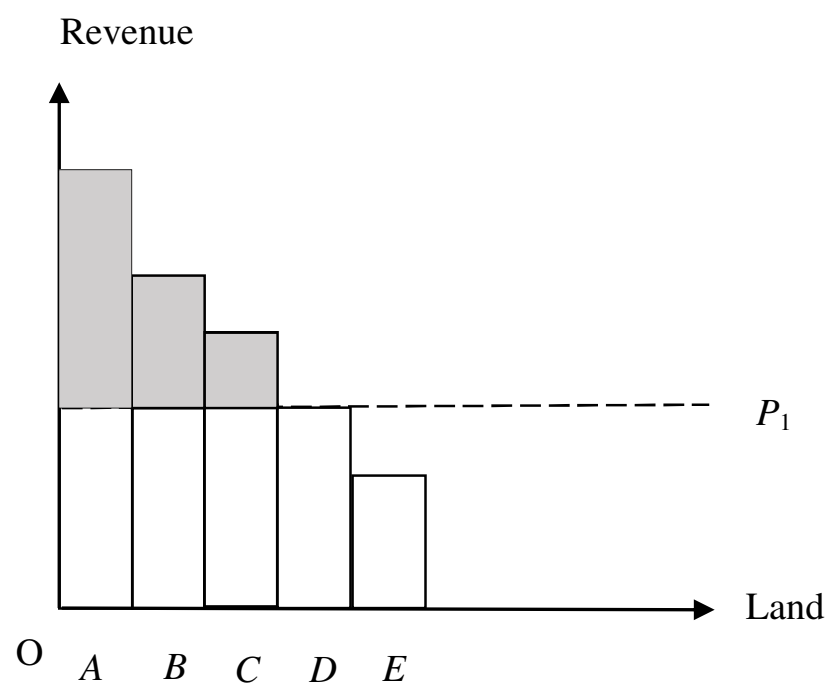

Figure 1: Differential rent of the first form $(D R I)$

A set of diagrams to depict the rents is in order. Figure 1 depicts $D R I$ I. A, B, C, D and $E$ indicate five different lands of descending fertility. They are of same size, each of them has the same capital invested on it. The heights of the rectangles indicate the revenue from crops. If price of crop changes the heights change proportionately. Production from $A, B, C$ and $D$ are enough to satisfy the demand. $D$ is therefore the marginal land. Its total price of production, say $P_{1}$, the height of the rectangle at $D$, determines the governing market price: market price, $p_{1}=$ 
$\frac{P_{1}}{\text { Output of } D} \cdot p_{1}$ is thus the unit price of production of $D$. At this price $A, B, C$ generate surplus profit, since their revenue is more than $P_{1}$. The surplus profit ( $\left.D R I\right)$ of each land is given by the height of the grey coloured rectangles above the horizontal line $P_{1}$. E is not under cultivation, since its revenue is below $P_{1}$. As more demand arises, output of $E$ would be required to satisfy the additional demand. Higher demand leads to price rise, which elongates each rectangle until height of $E$ is equal to $P_{1}$. The market price at this stage will be higher, given by $\frac{P_{1}}{\text { output of } E}$. Output of $E$ is less than output of $D$, indicating that price has gone up. In this new condition, all inframarginal lands will earn more $D R I$ since each rectangle is taller now.

Revenue

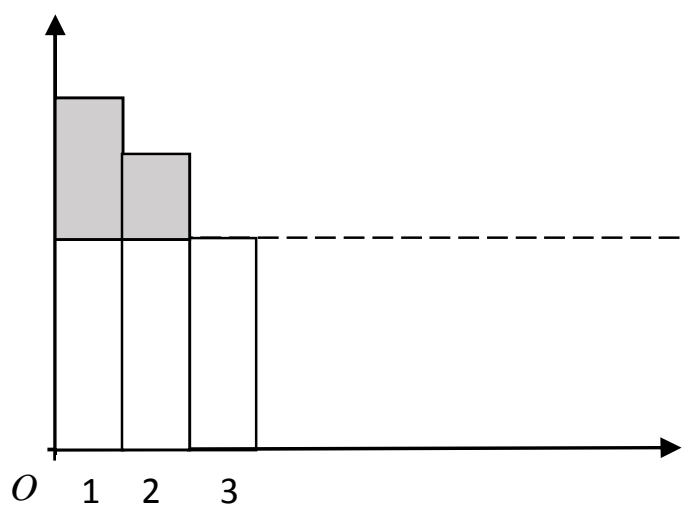

Panel 1: Land $A$
Revenue

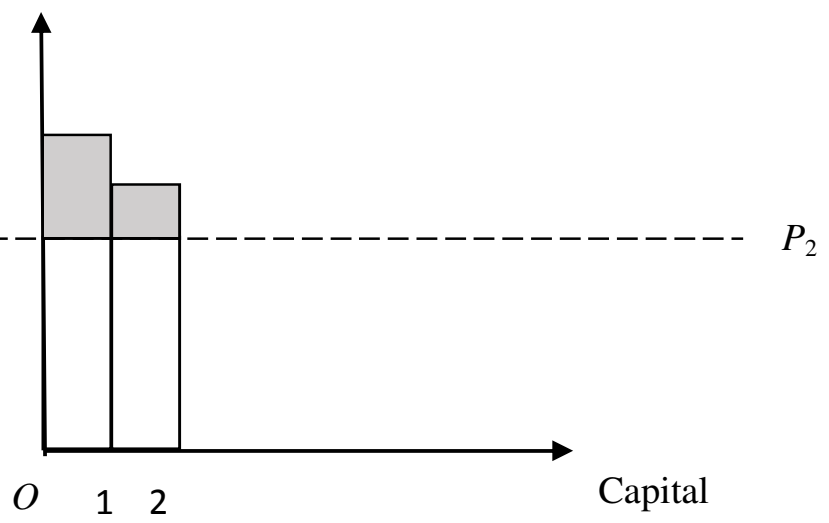

Panel 2: Land $B$

Figure 2: Differential rent of the second form $(D R I I)$

Figure 2 depicts $D R I I$. Two lands, land $A$ and land $B$ are under cultivation. On each land successive units of capital have been applied. The height of each rectangle represents revenue from output produced by each unit of capital. First three units of capital in land $A$ and first two units of in land $B$ are sufficient to satisfy demand. The third capital on $A$ is the marginal capital, as it is the least productive. Its total price of production i.e., the height of the rectangle at 3 will determine the market price. Market price, i.e. the unit price of production, is say, $p_{2}=$ $\frac{P_{2}}{\text { Output of capital } 3 \text { in } A}$. At this unit price of production, the first two capitals of both lands earn surplus profits. These surplus profits are indicated by the grey rectangles. For each land the 
summation of areas of the rectangles forms the differential rent. For land $B, D R I I$ is simply the sum of the two grey rectangles above 1 and 2 in panel 2. For land $A$, however, the differential rent, which is sum of the two grey rectangles in panel 1, is composed of $D R I$ and $D R I I$. DR I is given by the difference in the revenue from the first capitals of $A$ and $B^{6}$. If $D R I$ is subtracted from the differential rent of land $A D R I I$ is obtained. Compared to the situation where there was no $D R I I$, here crop price is higher.

Finally, $A R$ requires that agricultural sector's surplus value does not get eroded through competition. This principle of preservation of value determines the price. Suppose there are $l$ units of capital employed in agriculture, each has the same organic composition and each producing $v$ amount of value. Suppose $Y$ is the aggregate output produced by these $l$ units of capital. Then $A R$ would warrant that the price be equal to $p_{3}$ given by,

$p_{3} . Y=l . v$

This equation is a mathematical way of saying that the agricultural output must be sold at a price that guarantees that the value produced in agriculture remains within it. However, there is no certainty that $p_{3}$ be greater or equal to $p_{2}$, the price that guarantees normal profit to the least productive capital. If $p_{3}$ is less than $p_{2}$ then capital may move out of agricultural sector. Hence we need the condition $p_{3} \geq p_{2}$. We shall come back to this point in the next section.

\section{A Model}

In this section the three rents mentioned above will be gradually integrated in a mathematical model.

\subsection{DR I}

Suppose there are $n$ lands of same size, denoted by $1,2, \ldots, n$. The output of these lands are $y_{1}$, $y_{2}, \ldots, y_{\mathrm{n}}$, respectively, where, $y_{1}>y_{2}>\ldots>y_{n}$. Let $k$ be the volume of capital invested on each of them. Measured in monetary units, $k$ is composed of several kinds of goods. For simplicity we assume that the entire value of $k$ gets transferred to the crop produced, i.e. the rate of depreciation is $100 \%$. The price of crop is denoted by $p$. The normal rate of profit is assumed to be $r^{*}$. We assume $r^{*}$ is economy's overall profit rate $r_{s}, r^{*}=r_{s}$.

Once we deduct the profit and cost from the revenue, we get the surplus profit, or $D R I=p . y-$ $\left(1+r^{*}\right) k$

For any land $i$, the $D R I$ is given by, 
[1] $D R I_{i}=p \cdot y_{\mathrm{i}}-\left(1+r^{*}\right) k$

If all $n$ lands are under cultivation, the last land, that is, the marginal land, earns no surplus profit. Thus, $D R I$ of the $n$-th land is zero. What is the price which ensures that all $n$ lands would be under cultivation? Let $p_{n}$ be the level of price at which the following condition [2] is satisfied, then the price which would make $n$ lands worth cultivating must be equal to or more than $p_{n}$.

[2] $p_{n} \cdot y_{n}-\left(1+r^{*}\right) k=0$

Or, $p_{n} \cdot y_{n}=\left(1+r^{*}\right) k$

$p_{n}$ is the unit price of production of the $n$-th land. From [1] and [2] it's clear that at $p_{n} D R I$ is positive for all lands except the $n$-th land. From the 1 st to the $n$-th land, the DR I's follow a descending order.

Using [2] we can rewrite [1] as,

[3] $D R I_{i}=p_{n}\left(y_{\mathrm{i}}-y_{\mathrm{n}}\right)$

\subsection{DR II}

Suppose lands $1,2, . ., n$ have been be invested with $l_{1}, l_{2}, \ldots, l_{n}$ units of capital. Each unit of capital is of size $k$. Output produced by the $j$-th capital on the $i$-th land is $y_{i}^{j}$. Therefore the output produced by the marginal (last) capital on the $i$-th land is $y_{i}^{l_{i}}$. What is DR II of each land? Estimation of $D R I I$ depends on the price of production of the marginal capital. The marginal capital or the least productive capital could have been invested on any of the $n$ lands. Suppose the $m$-th land has the least productive investment, where $1 \leq m \leq n$. In other words, in the $m$-th land the last unit of capital $\left(l_{m}\right.$-th) is the least productive of all capitals.

$y_{m}^{l_{m}}=\operatorname{Min}\left(y_{1}^{l_{1}}, y_{2}^{l_{2}}, \ldots, y_{n}^{l_{n}}\right)$

Let us assume that the unit price of production of the $l_{m}$-th capital be $p_{m}^{l_{m}}$.

[4] $p_{m}^{l_{m}} \cdot y_{m}^{l_{m}}=\left(1+r^{*}\right) k$

Note from [2] and [4] it follows, $p_{m}^{l_{m}}>p_{n}$, since $y_{n}>y_{m}^{l_{m}}$

Now, for land 1, each capital invested on it is more productive (or equally productive) than the marginal capital. Hence each capital earns a surplus profit at price $p_{m}^{l_{m}}$. The differential rent of land 1 , composed of both sorts of differential rents, is the sum total of these surplus profits. So differential rent of the first land is given by,

$D R_{1}=p_{m}^{l_{m}}\left[y_{1}^{1}-y_{m}^{l_{m}}\right]+p_{m}^{l_{m}}\left[y_{1}^{2}-y_{m}^{l_{m}}\right]+\ldots+p_{m}^{l_{m}}\left[y_{1}^{l_{1}}-y_{m}^{l_{m}}\right]$ 
$=p_{m}^{l_{m}}\left[\sum_{j}^{l_{1}} y_{1}^{j}-l_{1} \cdot y_{m}^{l_{m}}\right]$

In general, for the $i$-th land the differential rent is given by,

[5] $D R_{i}=p_{m}^{l_{m}}\left[\sum_{j=1}^{l_{i}} y_{i}^{j}-l_{\mathrm{i}} \cdot y_{m}^{l_{m}}\right]$

With this extension of the model equation [3] has to be modified. This is given by [6] below.

[6] $D R I_{i}=p_{m}^{l_{m}}\left[y_{i}^{1}-y_{n}^{1}\right]$

If $D R I$ is subtracted from the total differential rent, $D R$, one obtains $D R I I$.

$D R_{i}=p_{m}^{l_{m}}\left[\sum_{j=1}^{l_{i}} y_{i}^{j}-l_{\mathrm{i}} \cdot y_{m}^{l_{m}}\right]$

$=p_{m}^{l_{m}}\left[y_{i}^{1}-y_{n}^{1}\right]+p_{m}^{l_{m}}\left[y_{n}^{1}-y_{m}^{l_{m}}\right]+p_{m}^{l_{m}}\left[\sum_{j=2}^{l_{i}} y_{i}^{j}-\left(l_{\mathrm{i}}-1\right) \cdot y_{m}^{l_{m}}\right]$

Therefore,

$D R_{i}=D R I_{i}+D R I I_{i}$

Where,

[8] DR II $=p_{m}^{l_{m}}\left[y_{n}^{1}-y_{m}^{l_{m}}\right]+p_{m}^{l_{m}}\left[\sum_{j=2}^{l_{i}} y_{i}^{j}-\left(l_{\mathrm{i}}-1\right) \cdot y_{m}^{l_{m}}\right]$

$D R I I$ is the summation of the difference in productivity between the first capital of the worst land and the worst capital, and the difference in productivity of other capitals on the $i$-th land with the worst capital. It is easy to see that $D R I I_{i}$ is non-negative, because each of the terms in the square brackets in [8] is non-negative.

What is the intuition behind [8]? DR II arises because capital invested differs across plots. Take the counter-factual: suppose capital invested does not differ, all are one unit of $k$. By [8] will $D R$ II disappear? The answer is, yes. $y_{m}^{l_{m}}$ is the output of the least productive capital. So, $y_{n}^{1}=y_{m}^{l_{m}}$. Hence the first term in the squared brackets on the RHS is zero. In the second term, $\left(l_{\mathrm{i}}-1\right)=0$. $y_{i}^{j}$ is also trivially zero, since there is no second unit of capital. Thus, DR II is zero when plots gets one unit of capital each.

\subsection{AR}

Surplus value $(S)$ formed by unpaid labour of workers. It is in proportion to variable capital $(V)$. We assume, after Marx, that this proportion, $\frac{S}{V}$, called the degree of exploitation, is constant across all spheres of production. Let this be,

[9] $e=\frac{S}{V}$ 
We also assume that the organic composition of capital in all agricultural activities is same, and it's given by $\alpha$,

[10] $\alpha=\frac{C_{a}}{V_{a}}$

$C_{a}, V_{a}$ and $S_{a}$ are the constant, variable capital and surplus value of agricultural investment $k$. It is assumed that $\alpha$ is lower than the organic composition of the rest of the economy. The average social organic composition is assumed to be $\beta, \alpha<\beta$.

The rate of profit, $r$, in general, is given by, $r=\frac{S}{C+V}$

$S$ is the surplus value produced by employing $C$ and $V$ amount of constant and variable capital.

Or, $r=\frac{\frac{S}{V}}{\frac{C}{V}+1}=\frac{e}{\frac{C}{V}+1}$

Let us recall $r_{a}$ and $r_{s}$ are the rates of profit in agricultural sector and the average rate of profit respectively. Using the above formula of $r$,

$r_{a}=\frac{e}{\frac{C_{a}}{V_{a}}+1}$

Or,

[11] $r_{a}=\frac{e}{\alpha+1}($ using [10])

Similarly, $r_{s}=\frac{e}{\frac{C_{S}}{V_{S}}+1}$, where $C_{\mathrm{s}}$ and $V_{\mathrm{s}}$ are the value of constant and variable capital of the economy as a whole.

Or,

$r_{s}=\frac{e}{\beta+1}$

Since $\alpha<\beta$,

[12] $r_{a}>r_{s}$

Let, the sum total of number of investments be $l$, i.e. $l=\sum_{i=1}^{n} l_{i}$. Let $Y$ be the sum total of output from all capital investments.

$Y=\left(y_{1}^{1}+y_{1}^{2}+. .+y_{1}^{l_{1}}\right)+\left(y_{2}^{1}+y_{2}^{2}+. .+y_{2}^{l_{2}}\right)+\ldots+\left(y_{n}^{1}+y_{n}^{2}+. .+y_{n}^{l_{n}}\right)$

Let, $l . v=\mathrm{p}_{3} . Y$ 
Here $v=$ value produced by $k$ magnitude of capital. $p_{3}$ ensures that revenue from the output produced by all units of capital be equal to the aggregate value.

Or, $p_{3}=\frac{l}{Y} \cdot v$

Now, $v=V_{a}+C_{a}+S_{a}=V_{a}(1+\alpha+e)$

Moreover we know,

$r_{a}=\frac{e}{\alpha+1}$

Implying, $e=r_{a}(1+\alpha)$. Substituting, we get,

[13] $p_{3}=\frac{l}{Y} \cdot V_{a}(1+\alpha)\left(1+r_{a}\right)$

On the other hand, we derived a formula of $p_{2}$ (equation [4]) which is the minimum price ensuring that the marginal capital earns the social rate of profit. $p_{2}$ is given by,

[14] $p_{2}=\frac{1}{y_{m}^{l_{m}}} V_{a}(1+\alpha)\left(1+r_{s}\right)$

$r_{s}$ is the rate of profit prevailing elsewhere in the economy.

Now, $p_{3}$ governs the market price. It cannot be less than $p_{2}$. If it is less than $\mathrm{p}_{2}$ then the marginal capital will earn a rate of profit less than elsewhere, hence will not get invested. So, the condition that needs to be satisfied is,

$[15] p_{3} \geq p_{2}$

Using [13] and [14], we get,

[16] $\frac{l}{Y} \cdot V_{a}(1+\alpha)\left(1+r_{a}\right) \geq \frac{1}{y_{m}^{l_{m}}} V_{a}(1+\alpha)\left(1+r_{s}\right)$

Simplifying,

$\left[16^{\prime}\right]\left(1+r_{a}\right) \geq\left(1+r_{s}\right) \frac{\frac{Y}{l}}{y_{m}^{l_{m}}}$

By [12] $r_{a}>r_{s}$. The marginal capital produces less output than the average output, implying $\frac{Y}{l}>$ $y_{m}^{l_{m}}$. For [16'] to be satisfied $r_{a}$ has to be sufficiently higher than $r_{s}$. Only when the difference between them is higher than a threshold, [16'] is satisfied and a state of rest is reached. It implies that the organic composition of capital in agriculture has to be sufficiently lower than the rest of the economy. 
Let us consider the marginal capital. $A R$ of this capital is the difference between value $(=$ price $=$ $p_{3}$ ) and the total price of production, imputed at the social rate of profit $r_{s}$. Thus absolute rent of the least productive capital is given by,

[17] $A R=p_{3} \cdot y_{m}^{l_{m}}-\left(1+r_{s}\right) k$

$=\frac{l}{Y} \cdot V_{a}(1+\alpha)\left(1+r_{a}\right) y_{m}^{l_{m}}-\left(1+r_{s}\right) k$

Using [16], one can see that $A R$ is non-negative.

For any land $i$, total rent $R_{i}$ is the sum total of all surplus profits earned by all capitals invested on it. So, it is given by,

[18] $R_{i}=p_{3} \cdot \sum_{j=1}^{l_{i}} y_{i}^{j}-\left(1+r_{\mathrm{s}}\right) l_{\mathrm{i}} \cdot k$

$l_{\mathrm{i}}$ is the number of units of capital invested on the $i$-th land. By [15], $A R$ of the least productive capital is non-negative, i.e. $p_{3} . y_{m}^{l_{m}}-\left(1+r_{s}\right) k \geq 0$. Hence $R_{i}$ is positive.

Evaluating the differential rent $D R_{i}$ at $p_{3}$, we get from [5],

$D R_{i}=p_{3}\left[\sum_{j=1}^{l_{i}} y_{i}^{j}-l_{\mathrm{i}} \cdot y_{m}^{l_{m}}\right]$

Rewriting [18], we get,

$R_{i}=p_{3} \cdot \sum_{j=1}^{l_{i}} y_{i}^{j}-p_{3} \cdot l_{\mathrm{i}} \cdot y_{m}^{l_{m}}+p_{3} \cdot l_{i} \cdot y_{m}^{l_{m}}-\left(1+\mathrm{r}_{\mathrm{s}}\right) l_{\mathrm{i}} \cdot k$

$=D R_{i}+l_{\mathrm{i}} \cdot A R($ by [17])

So,

[19] $A R_{i}=l_{\mathrm{i}} \cdot A R=R_{i}-D R_{i}=l_{\mathrm{i}}\left[p_{3} \cdot y_{m}^{l_{m}}-\left(1+r_{\mathrm{s}}\right) k\right]$

The absolute rent of a land is the units of capital invested on it multiplied by the absolute rent earned by the least productive capital. This is not surprising, because all capitals have the same value and same organic composition. $A R$ earned by the least productive capital would be the same as earned by any other capital.

The three elements of rent are now put together. Since $p_{3}$ guaranteeing $A R$ is the price, we modify the equations [6] and [8] as given below in [6'] and [8'].

[6'] $D R I_{i}=p_{3} \cdot\left[y_{i}^{1}-y_{n}^{1}\right]$

$\left[8^{\prime}\right] D R I I_{i}=p_{3} \cdot\left[y_{n}^{1}-y_{m}^{l_{m}}+\sum_{j=2}^{l_{i}} y_{i}^{j}-\left(l_{\mathrm{i}}-1\right) \cdot y_{m}^{l_{m}}\right]$

[19] $A R_{i}=l_{\mathrm{i}} \cdot\left[p_{3} \cdot y_{m}^{l_{m}}-\left(1+r_{\mathrm{s}}\right) k\right]$

One needs to know $p_{3}$ to estimate [6'], [8'] and [19]. This is given by [13]. 
[6'], [8'], [19] and [13] provide the estimation of the three forms of rent. If data of output, capital, degree of exploitation are known, one can use the equations to estimate the rents.

\section{Rent Theory and Indian Agriculture}

How is the above discussion useful in understanding contemporary Indian agriculture? In this framework land is owned by the landlord, from whom the capitalist farmer leases it in lieu of payment of rent. The capitalist farmer employs agricultural workers to produce surplus value. This is like production in any industry, where relations of production are capitalist. In contrast, Indian agriculture is far from attaining the capitalist mode of production. This is a widely shared observation and is supported by empirical evidences (Patnaik 1983, Basu and Das 2013, Das 2016). Petty farms, owning land less than 2 or 1 hectares of land and relying on family labour dominate the agrarian scene. The small peasants usually own the land they cultivate.

In theory a process of "peasant differentiation" is supposed to ensue from this state. Superior productive power of large farms and the force of accumulation are supposed to put petty farms out of business. Historically different societies have thrown up multifarious routes through which transition occurred. As is well known, these were clubbed under two broad categories, the Prussian path and the American path by Lenin (1907). The first entails gradual evolution of feudal lords into capitalist farmers, or capitalism from above. The second path is capitalism from below: peasants evolve into capitalist farmers, in some cases through revolution ${ }^{7}$. In either way, "industrialisation of agriculture" takes place, capitalism comes to characterise the mode of production. In contrast, in India, the share of small farms in terms of number and area has been rising inexorably. There are patches of area where the top deciles of the farms have gained in terms of assets and even land. But this is not a general trend (Das 2015).

The theoretical tools that were deployed by Marx can still be applied in a peasant proprietor dominated economy. The creation of value takes place in such an economy. Existence of value, to wit exchange value, requires that production is for the purpose of exchange ${ }^{8}$. This condition is widely satisfied in such an agrarian economy. Existence of surplus value requires separation of labourers from the means of production; the latter are owned by capitalists who by ensuring that value of the labour power stay less than the value produced by labourers exact the difference as 
surplus value 9 . However, Marx was not consistent in applying the idea of surplus value to capitalist agriculture exclusively. For instance in Capital III surplus value appears in "smallscale peasant ownership" economy ${ }^{10}$. To our mind, surplus value in these cases is notional, not actual. This notional surplus value is the difference between value and value of labour power where value of labour power is estimated by imputing wage rate prevailing elsewhere in agriculture to the number of hours performed by the peasant family.

If we venture to apply the Marxist analytical tools in peasant propeietroship economy, albeit with qualifications, a second conundrum arises. Rent acted as a barrier to capital flow in the original framework. The landlords took away a part of the surplus profit which otherwise would have accrued to the landowning capitalist farmer. In contrast, in peasant proprietorship economy the petty peasants do not pay rent since they own the land. If there is no rent to pay, there is no rent barrier. It follows that capital investment would quicken. But, evidences do not indicate a fast accumulation of capital.

Although Marx did not spend much time on peasant proprietor dominated agrarian economy, his followers did so as they attempted to apply Marx's theory. Commenting on a situation of falling ground rent Kautsky ([1899] 2007) wrote that declining ground rent led to, "a crisis in agriculture which...is chronic in character, especially in those areas where, as in most countries, the landowner and farmer are one and same individual, so that a loss to the landowner is also a loss to the farmer" (italics added). This observation is useful in understanding the predicament of Indian peasants. Being the owner of the land, the peasant earns rent in an implicit manner. In a condition of declining ground rent, her income falls. But why does the ground rent fall?

From the discussion of section 2 and 3 it follows that as market price falls, rents tend to decline. Let us consider absolute rent, $A R$, for instance. $A R$ is the difference between value and average price of production. If market price is above the average price of production the owner of the land earns $A R$. By limiting the supply of land thereby raising crop price, big landlords try to ensure that the market price stays above the price of production, such that $A R$ is obtained. But whether they would succeed in doing it in reality depends on the balance of class forces. The landlords have few instruments to keep the price high in an adverse condition, when the balance 
is a tilting against them and towards the big bourgeoisie, when there is less restrictions on the import of agricultural commodities, when land holdings are getting subdivided and fragmented ${ }^{11}$. The resulting collapse of crop price hurts all owners of land, and not only the big landlords. Petty peasants, being the largest constituent of landowners, lose out as a result.

Petty farmers also lose out as earners of profit. As the price of crop collapses, the farmers may not even get the average rate of profit, which capitalists of the economy normally earn. Instead of being higher than the price of production, crop price may dip below it. The fact that profit rate in Indian agriculture is alarmingly low, negative in some cases, indicates that such a state of affairs could be present ${ }^{12}$. A low profit rate adversely affects the condition of farm labourers as well. It's possible that low crop price may benefit them as buyers of crop (food grain for example). But a depressed state of cultivation implies low demand for labour, which diminishes prospects of finding jobs. Petty peasant, relying on wage income to supplement the meagre income from land, lose out on this count as well.

\section{Conclusion}

Marx's rent theory is a painstakingly detailed body of scholarship. It is consistent with his theory of value. In spite of its obvious relevance, few scholarly works have attempted to view Indian agriculture through the Marxist framework. The present paper integrates different components of Marx's rent theory in a single model. In Marx's theory landed property acted as a barrier to capital inflow. In an economy like India where small peasant proprietors dominate in contrast, a similar phenomenon of lack of inflow of capital could be present nonetheless. The gradual loss of power of landlords and liberal import of farm products depress crop prices. This discourages investment in farming. Capital accumulation remains slow. The dismal condition of peasants continues.

\section{References}

Agarwal, B and A Agarwal (2017): "Do farmers really like farming? Indian farmers in transition", Oxford Development Studies 45(4):460-478. 
Basu, D (2018): "Marx's Analysis of Ground-Rent: Theory, Examples and Applications", Working Paper 2018-04, Department of Economics, University of Massachusetts Amherst, retrieved on April 25, 2018 (https://www.umass.edu/economics/publications/2018-04.pdf)

Basu, D and D Das (2013): "The Maoist Movement in India: Some Political Economic Considerations", Journal of Agrarian Change 13(3): 365-381.

Basu, D and D Das (2018): “Profitability in India's Organized Manufacturing Sector: The Role of Technology, Distribution and Demand”, Cambridge Journal of Economics 42(1): 137-153.

Chatterjee, P (2008): "Democracy and Economic Transition in India", Economic and Political Weekly 45 (16): 53-62.

Das, D (2015): "Changing Distribution of Land and Assets in Indian Agriculture", Review of Radical Political Economics, Vol. 47(3) 412-423.

Das, D (2016): “Agricultural Investment in India in Recent Decades: A Political Economic Note of Its Causes and Consequences", p. 286-299 in Economic Challenges for the Contemporary World: Essays in Honour of Prabhat Patnaik, edited by M. Das, S. Kar, N Nawn, New Delhi: Sage Publishing.

Fine, B (1979): “On Marx's theory of agricultural rent”, Economy and Society, 8(3): 241-278.

Government of India (2017): Price Policy for Kharif Crops: The Marketing Season 2017-18, Commission of Agricultural Costs and Prices, Ministry of Agriculture, retrieved on April 25, 2018 (https://cacp.dacnet.nic.in/ViewReports.aspx?Input=2\&PageId=39\&KeyId=598).

Kautsky, K ([1899]2007): “The Capitalist Character of Modern Agriculture”, p. 187-226 in The Agrarian Question in Marx and His Successors Vol. I, edited by U. Patnaik. New Delhi: LeftWord Books.

Lenin, V I (1907): The Agrarian Programme of Social-Democracy in the First Russian Revolution, 1907-1907, retrieved on April 25, 2018 (https://www.marxists.org/archive/lenin/works/1907/agrprogr/ch01s5.htm\#v13pp72-238)

Mandel, E. (1990): “Karl Marx," p. 1-38 in Marxian Economics, edited by J Eatwell, M Milgate and P Newman, London 1990, retrieved April 25, 2018 (https://www.marxists.org/archive/mandel/19xx/marx/ch05.htm).

Marx, K([1887] 1976): Capital, Volume I, London: Penguin Classics.

Marx, K([1894]1981):Capital, Volume III, London: Penguin Classics.

Marx, K (1863): Theories of Surplus-Value, retrieved August 25, 2018 (https://www.marxists.org/archive/marx/works/1863/theories-surplus-value/ch11.htm\#s1) 
Patnaik, U (1983): "Classical theory of rent and its application to India: Some preliminary propositions, with some thoughts on sharecropping", The Journal of Peasant Studies 10 (2-3): 71-87.

Smith, A ([1776] 1970): The Wealth of Nations, London: Penguin Classics.

\footnotetext{
${ }^{1}$ Few exceptions such as Patnaik (1983) exist.

2" The analysis of landed property in its various historical forms lies outside the scope of the present work...We assume therefore that agriculture, just like manufacturing, is dominated by the capitalist mode of production"(Marx [1894] 1981, p. 751, emphasis added).
}

${ }^{3}$ Diminishing marginal productivity of capital would imply this. But the assumption of diminishing marginal productivity is not necessary to get $D R I I$.

${ }^{4}$ Note, as the price of agricultural produce changes from 30 to 20 between the two cases, capital advanced (50) is assumed to remain unchanged. This can be disputed. If agrarian produce includes food grain, change in its price may affect money wage of agrarian workers and hence the capital advanced. We have ignored this complication since the conclusion we draw is going to remain unaffected even if a part of the capital advanced rises due to crop price increase.

${ }^{5}$ To be precise $A R=$ value - price of production is true under the assumption that value and price are same. In general, $A R$ is the gap between market price and the price of production, provided price not above value. In other words,

$$
\begin{aligned}
A R(\text { per unit })= & \text { Min }(\text { value }, \text { market price })-\text { unit price of production, if Min (value, } \\
& \text { market price })>\text { unit price of production } \\
= & 0, \text { otherwise. }
\end{aligned}
$$

"Since however the value of the commodities produced by agricultural capital is above their price of production, by our assumption, this rent $[A R]$ forms the excess of the value above the price of production, or a part of this excess" (Marx [1894] 1981, p. 896).

${ }^{6}$ This means in estimating $D R I$ capital invested on each land in taken to be one unit. This may appear arbitrary. But it had to be so, since $D R I$ only requires that same capital be invested on each land. We kept the same capital volume at 1 unit.

${ }^{7}$ Lenin (1907) wrote:

[T]wo paths of objectively possible bourgeois development we would call the Prussian path and the American path, respectively. In the first case feudal landlord economy slowly evolves into bourgeois, Junker landlord economy, which condemns the peasants to decades of most harrowing expropriation and bondage, while at the same time a small minority of Grossbauern ('big peasants') arises. In the second case there is no landlord economy, or else it is broken up by revolution, which confiscates and splits up the feudal estates. In that case the peasant predominates, becomes the sole agent of agriculture, and evolves into a capitalist farmer.

This categorisation could be an extension of what Marx ([1894] 1981, p. 452) said of transition in general: 
The transition from the feudal mode of production takes place in two different ways. The producer may become a merchant and capitalist, in contrast to the agricultural natural economy and the guild-bound handicraft of medieval urban industry. This is the really revolutionary way. Alternatively, however, the merchant may take direct control of production himself.

8" What exclusively determines the magnitude of the value of any article is therefore the amount of labour socially necessary, or the labour-time socially necessary for its production," Marx ([1887] 1976, p. 130) observed and went on to approvingly quote: "The value of them' (the necessaries of life) "when they are exchanged the one for another, is regulated by the quantity of labour necessarily required, and commonly taken in producing them.' ". Note, this applies irrespective of the nature of mode of production.

${ }^{9}$ Marx ([1887] 1976, p. 251) introduced surplus value in the chapter 4 of Capital I titled "The General Formula for Capital": "The complete form of this process is therefore M-C-M', where $\mathrm{M}^{\prime}=\mathrm{M}+\Delta \mathrm{M}$, i.e. the original sum advanced plus an increment. This increment or excess over the original value I call 'surplus-value'." The existence of the capitalist is necessary in this process, the end of production here is not creation of use value but of exchange value.

10، Here the peasant is the free proprietor of his land, which appears as his main instrument of production, as the indispensable field of employment for his labour and his capital. No lease-price is paid in this form; thus rent does not appear as a separate form of surplus-value..." (Marx [1894] 1981, p. 940, italics added).

${ }^{11}$ See Chatterjee (2008), for instance, on the falling heft of landlords vis-à-vis the big bourgeoisie.

12 The Commission for Agricultural Costs and Prices reported the return farmers earned over $C_{2} \operatorname{cost}$ of cultivation in 2014-15 kharif season (table 5.1, Government of India 2017). $C_{2}$ is a comprehensive estimate of costs including imputed rent of land, wage of family labour, etc. This return can be treated as profit rate. For a number of crops, for instance jowar, bajra, ragi, profit rate was negative. For paddy, the most popular crop, the return was a miserly $8 \%$. One can contrast this with the high profit rates earned in the organised manufacturing sector (Basu and Das, 2018). See Agarwal and Agarwal (2017) on a study of farmers' willingness to quit farming. Low profitability was found to be a major reason for wanting to give up farming. 